\title{
Negative effects of mass tourism on high mountain fauna: the case of the Tatra chamois Rupicapra rupicapra tatrica
}

\author{
ŁuKASZ PęKSA and MiChaє CiaCh
}

\begin{abstract}
Until recently animals inhabiting mountain areas were relatively free from disturbance by people but they are now coming under increasing pressure. Tourism, especially that involving large numbers of people, is having an ever more detrimental effect on the natural resources of high mountains, even in protected areas. We analyse the effect of tourist pressure on the population of the Tatra chamois Rupicapra rupicapra tatrica, which inhabits the strictly protected high-altitude habitats of the Tatra mountains (Carpathians, Poland). The Kasprowy Wierch cable car system, in operation since 1936, was modernized in 2007; as a consequence $50 \%$ more people can now be carried into the chamois' habitat. The effect of this sudden increase in tourist pressure has been to reduce the size of herds (3.9 vs 5.3 individuals) and to increase the distance between the animals and the cable car station (1,664.0 vs $693.0 \mathrm{~m})$, the cable car infrastructure $(1,415.0$ vs $467.8 \mathrm{~m})$ and adjacent skilifts and ski pistes (1,214.2 vs $494.3 \mathrm{~m})$. The distance to the marked hiking trails has not changed, however. Following the modernization of the cable cars, larger herds of chamois have been seen at greater distances from the tourist infrastructure. Our results indicate the adverse impact of this mass tourism. Human activities in high-mountain ecosystems need to have due consideration for the requirements of wild species, and the number of visitors needs to be controlled.
\end{abstract}

Keywords Chamois, human impact, mass tourism, mountain, Poland, protected areas, Rupicapra rupicapra tatrica, Tatra National Park

\section{Introduction}

F or a long time the ecology of animals inhabiting high- mountain habitats was little studied because of the inaccessibility of these environments (Krajick, 1999). As a consequence, the significance of mountains in the preservation of biological diversity was frequently underestimated. The habitat and climatic conditions of high mountains

Łukasz PĘKSA Tatra National Park, Zakopane, Poland

Michą Ciach (Corresponding author) Department of Zoology and Wildlife Management, Faculty of Forestry, Forest Biodiversity Institute, University of Agriculture, al. 29 Listopada 46, 31-425 Kraków, Poland

E-mail michal.ciach@ur.krakow.pl

Received 2 February 2013. Revision requested 29 April 2013.

Accepted 6 September 2013. First published online 11 August 2014. support species with narrow and highly specific ecological requirements (Körner, 2004; Spehn \& Körner, 2005). Highmountain species, formerly relatively undisturbed by human influence, have in recent decades been subjected to ever greater anthropogenic pressure. Habitats are being transformed and degraded as a result of mining, overgrazing, climate change and other influences, and tourism is having increasingly deleterious effects on the natural resources of high mountains, including in protected areas. The spatial and temporal concentration of tourism, tourist infrastructure, forms of recreation and the behaviour of tourists may all have potentially negative impacts on wild species and their habitats (Gössling, 2002; Zaręba, 2008).

One of the most significant threats to high-mountain environments comes from people entering them (Beale \& Monaghan, 2004), and from the noise they make and their motor vehicles (Holmes et al., 1993). Activities such as skiing, motoring, hiking and climbing can all contribute to the degradation and loss of mountain habitats and to changes in the behaviour of the species living there (Gander \& Ingold, 1997; Camp \& Knight, 1998a,b; Thiel et al., 2005, 2007, 2008; Zwijacz-Kozica et al., 2013). As they often have restricted ranges, these species are sensitive to environmental change. Increasing human disturbance in their habitats may have potentially catastrophic consequences (Ewers \& Didham, 2006).

The Tatra Mountains are one of the few mountain ranges in central Europe that support high-mountain flora and fauna. Human activities have influenced this area for $>200$ years but the region is now protected as a national park. The only human pressure still affecting this area comes from tourism: hiking, climbing, caving and skiing, along with associated amenities such as hostels, the mountain rescue service, restaurants and transport. As many as 2.7 million people visit the Polish Tatra Mountains every year.

As a result of the construction in 1936 of a cable car to Kasprowy Wierch, a peak in the central Polish Tatra Mountains, the area around it became anthropogenically transformed. In addition to the upper terminal of the cable car there are two ski lifts and ski pistes (Gąsienicowa Valley and Goryczkowa Valley) and a weather station. Every day in the summer 2,000-3,000 people reach the summit on foot (Czochański, 2002) and until recently the cable car brought an additional 1,200-1,300 people daily (Skawiński \& Krzan, 2002). The large numbers of people visiting these mountains could be having an adverse impact on this environment, including on the Tatra chamois Rupicapra rupicapra 
tatrica (Zwijacz-Kozica et al., 2013). Although the chamois Rupicapra rupicapra is categorized as Least Concern on the IUCN Red List (Aulagnier et al., 2008), the subspecies R. rupicapra tatrica is categorized as Critically Endangered in the European Mammal assessment and in the Polish Red Data Book (Gąsienica-Byrcyn, 2001).

The infrastructure of the cable car to Kasprowy Wierch was modernized during 2007-2008, with the cable cars, their support masts and cables changed or rebuilt, to speed the flow of passengers and to carry more people to the mountain tops. In effect, an unplanned experiment has taken place, increasing human pressure in a strictly protected highmountain habitat. The objective of the present research was to assess the influence of the increasing number of people on the numbers and distribution of the chamois. Our hypothesis was that the increase in mass tourism in the areas inhabited by chamois had increased the distance between these animals and the places visited by people.

\section{Study area}

Lying in the central western Carpathians, the Tatra Mountains are the highest mountain massif between the Alps and the Caucasus. The area has an alpine landscape with altitudinal zonation of climate and vegetation, including alpine meadows and a sub-nival zone. The mountains cover an area of c. $800 \mathrm{~km}^{2}$, c. $20 \%$ of which lies within Poland. The highest peak is Gerlach $(2,655 \mathrm{~m})$.

The Tatra Mountains are protected in their entirety as national parks: the Tatranský Národný Park in Slovakia (designated in 1949) and the Tatrzański Park Narodowy (Tatra National Park) in Poland (designated in 1954). On the basis of their biodiversity and unique geomorphology the Tatra Mountains are a UNESCO World Biosphere Reserve and are included in the Natura 2000 network of protected areas in Europe.

The peak of Kasprowy Wierch $(1,987 \mathrm{~m})$ in the central part of the Polish Tatra Mountains rises at the meeting point of three extensive valleys. It has a temperate but highmountain climate. The mean annual air temperature is $-0.7^{\circ} \mathrm{C}$, snow covers the ground for an average of 221 days per year, and the mean annual precipitation is nearly 1,800 mm (Limanówka et al., 2008).

The modernization of the infrastructure of the cable car system to Kasprowy Wierch during 2007-2008 included support masts and cables and a doubling of the size of the cable cars. The works required c. 6 months, with the use of heavy equipment that generated extensive noise, supply of materials and the presence of workers.

\section{Methods}

The field work was carried out before (1999-2001) and after (2008-2010) modernization of the cable car system. In both periods an $18 \mathrm{~km}$ transect through potential chamois habitat, across altitudes of 1,023-2,051 m, was surveyed (Fig. 1). In each survey the sizes and positions of chamois herds were recorded. Within the herd, sex and age (adult, first-year calf, second-year young) of individuals were recorded. Surveys were carried out twice per week during 06.00-18.0o between the beginning of June and the end of September. A non-stop walk along the transect took 6-7 hours but could take double this time when there were chamois to be observed. A total of 103 surveys were carried out during 1999-2001 and 104 during 2008-2010. The positions of the sighted herds were marked on $1: 10,000$ scale maps, from which a vector layer was produced.

Using the vector layer containing the chamois records and an orthophotomap of Tatra National Park (for 2009, resolution $25 \mathrm{~cm}$ ), the distances of the observed animals were measured to the nearest hiking trail, the upper cable car terminal on Kasprowy Wierch, the cable car support masts and cables, and the ski lifts and pistes in the Gąsienicowa and Goryczkowa Valleys. The measurements were made using ArcGIS v. 9.1 (ESRI, Redlands, USA), ignoring topographic irregularities.

To compare tourist pressure between the two research periods we used ticket sales from Tatra National Park and the Polish Cable Car Company; i.e. the number of people entering the National Park on foot and of passengers carried to Kasprowy Wierch, respectively. Monitoring data for Tatra National Park were used to compare the number of chamois between the two periods across the entire mountain range. These data were collected using a survey method established in 1932 by J. Müller (Chudík, 1969), in which an annual count, during October-November, is conducted simultaneously across the entire Tatra Mountains.

Statistics were calculated with Statistica v. 8.0 (StatSoft, Tulsa, USA), following Zar (1999). A squared transformation was used to normalize data. The Student's $t$-test was used to examine differences in the distance of chamois herds to infrastructure before and after modernization, Pearson's correlation coefficient to explore the relationship between herd size and distances to infrastructure for each period, a $\chi^{2}$ test to examine differences in sex ratio between the two periods, and a Mann-Whitney $U$-test to analyse differences in the number of second-year young within a herd between the two periods.

\section{Results}

During 1999-2001 a mean of 2,331,762 \pm SD 107,003 people visited Tatra National Park annually. This number did not differ significantly $(t=-0.44, \mathrm{P}=0.683)$ from the number of visitors during 2008-2010 (mean 2,391,157 \pm SD 208,565 per year). During 1999-2001, prior to the modernization of the cable car, a mean of $323,125 \pm$ SD 43,993 people were 


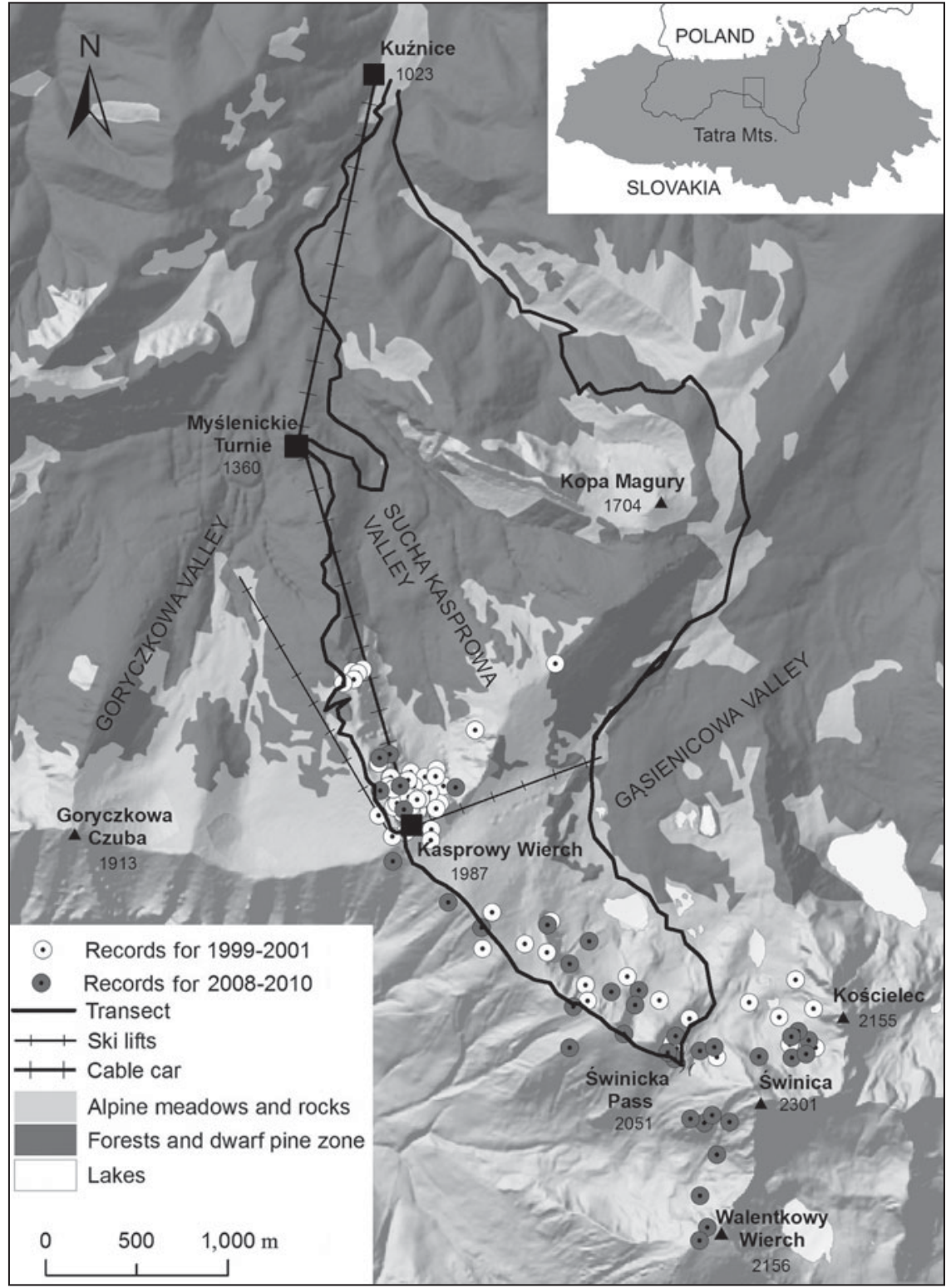

FIG. 1 Records of herds of the Tatra chamois Rupicapra rupicapra tatrica in the study area in the Tatra National Park (southern Poland) in two periods: before (1999-2001) and after (2008-2010) the modernization of the cable car to Kasprowy Wierch. The rectangle on the inset indicates the location of the main map in southern Poland. transported annually to the summit of Kasprowy Wierch by cable car; this rose to a mean of $479,915 \pm$ SD 62,862 per year during 2008-2010, after modernization. This increase was significant $(t=-3.54, \mathrm{P}=0.024)$. The mean annual chamois population in the entire Tatra National Park during 1999-2001 was $70 \pm 1 \mathrm{SD}$ individuals, significantly fewer $(t=-10.97, \mathrm{P}=0.000)$ than during 2008-2010 (mean $157 \pm 14 \mathrm{SD})$.

Before the cable car modernization, chamois were recorded on the Kasprowy Wierch massif 64 times but after modernization only 36 times (Fig. 1). There was a significant decrease in the mean chamois herd size between 1999-2001 and 2008-2010 (Table 1). After modernization the distance between the sites where chamois were recorded and parts of the tourist infrastructure changed: there was a significant increase in the distance between the chamois and the summit cable car station, cable car supporting masts and cables, and the ski lifts and pistes in the adjoining valleys (Table 1). The only parameter unchanged was the distance to the hiking trails.

At the same time, there was a change in the relationship between herd size and distance to parts of the tourist infrastructure. Prior to the cable car modernization, chamois herd size was inversely proportional to distance from the tourist infrastructure: larger herds were seen at closer distances (Table 2). After modernization, however, there was a positive correlation between herd size and distance from three of four elements of the tourist infrastructure (Table 2). Sex structure differed significantly between the two periods $\left(\chi^{2}=71.79, \mathrm{P}=0.000\right)$. Before the cable car modernization males and females constituted 8.4 and $91.6 \%$, respectively, $(n=155)$ of all recorded adult chamois. After modernization males and females constitute 14.0 and $86.0 \%$, respectively, $(n=50)$ of all 
TABLE 1 Mean herd size of the Tatra chamois Rupicapra rupicapra tatrica and the mean distance (with SD and range) of herds to parts of the tourist infrastructure in the Tatra National Park (Fig. 1) in two periods, before (1999-2001) and after (2008-2010) the modernization of the cable car taking tourists to Kasprowy Wierch, and Student's $t$-tests examining differences between the two periods.

\begin{tabular}{|c|c|c|c|c|c|c|}
\hline \multirow[b]{2}{*}{ Parameter } & \multicolumn{2}{|c|}{$\begin{array}{l}\text { Before modernization } \\
(\mathrm{n}=64)\end{array}$} & \multicolumn{2}{|c|}{$\begin{array}{l}\text { After modernization } \\
(\mathrm{n}=36)\end{array}$} & \multirow[b]{2}{*}{$t$} & \multirow[b]{2}{*}{$\mathrm{P}$} \\
\hline & Mean \pm SD & Range & Mean \pm SD & Range & & \\
\hline Herd size & $5.3 \pm 3.0$ & $1-12$ & $3.9 \pm 3.7$ & $1-19$ & 2.32 & 0.022 \\
\hline Distance to nearest hiking trail (m) & $144.3 \pm 111.9$ & $0-510$ & $190.4 \pm 178.9$ & $0-740$ & 0.11 & 0.910 \\
\hline Distance to upper cable car terminal (m) & $693.0 \pm 753.7$ & $63-2,523$ & $1,664.0 \pm 815.8$ & $92-2,779$ & -5.78 & 0.000 \\
\hline Distance to cable car support masts \& cables (m) & $467.8 \pm 644.8$ & $0-1,984$ & $1,415.0 \pm 788.6$ & $28-2,702$ & -5.58 & 0.000 \\
\hline Distance to ski lifts \& pistes (m) & $494.3 \pm 557.0$ & $0-1,941$ & $1,214.2 \pm 733.2$ & $61-2,324$ & -4.20 & 0.000 \\
\hline
\end{tabular}

TABLE 2 Pearson's correlation between herd sizes of the Tatra chamois and distance to parts of the tourist infrastructure in the Tatra National Park (Fig. 1) in two periods, before (1999-2001) and after (2008-2010) the modernization of the cable car taking tourists to Kasprowy Wierch.

\begin{tabular}{lllll}
\hline & \multicolumn{2}{l}{ Before modernization } & & \multicolumn{2}{c}{ After modernization } \\
\cline { 2 - 3 } & $r$ & $\mathrm{P}$ & & $r$ \\
\hline Distance to nearest hiking trail (m) & -0.49 & 0.000 & 0.21 & 0.209 \\
Distance to upper cable car terminal (m) & -0.54 & 0.000 & 0.39 & 0.019 \\
Distance to cable car support masts \& cables (m) & -0.56 & 0.000 & 0.40 & 0.016 \\
Distance to ski lifts \& pistes (m) & -0.51 & 0.000 & 0.41 \\
\hline
\end{tabular}

recorded adults. The number of second-year young accompanying female herds differed significantly between study periods $\left(Z_{\mathrm{c}}=4.35, \mathrm{P}=0.000\right)$. Before the cable car modernization the median number of second-year young was 2 (quartiles ${ }_{25-75}=2-3$, range $=0-4, n=48$ ); after modernization the median number of second-year young was o (quartiles $25-75=0-1$, range $=0-3, \mathrm{n}=20$ ).

\section{Discussion}

The results of this work show that a $50 \%$ increase in the number of tourists carried by cable car to the chamois' habitat has led to a decrease in herd size and an increase in the distance separating the animals and the cable car infrastructure. Only the distance between the chamois and the hiking trails has not changed significantly. More people now congregate near the summit cable car station and ski lifts/pistes, putting greater pressure on the adjacent areas, but this has not caused more people to go onto the hiking trails.

Human activities in high-mountain environments disturb animals (Cederna \& Lovari, 1985; Patterson, 1988; Ingold et al., 1996; Pépin et al., 1996; Schnidrig-Petrig \& Ingold, 2001). Repeated events elicit the most serious effects: the animals ultimately become accustomed to them, losing their fear and decreasing vigilance towards other unpredictable disturbances and dangers (Hamr, 1988; Gander \& Ingold, 1997). As a result of human disturbance, chamois have less time for foraging or resting (Enggist-Düblin \&
Ingold, 2003). This significantly raises the amount of energy they have to expend on moving away from sources of disturbance, and prolongs the amount of time devoted to vigilance (Parker et al., 1984; Bradshaw et al., 1998). Sibbald et al. (2011) demonstrated that animals may change their behaviour and dietary composition by abandoning foodrich areas. The result is that habitats are effectively lost, and that interspecific and intraspecific competition may increase in other areas, where food availability may be limited (Gordon \& Illius, 1989). This is a common situation in mountains, where the growing season is relatively short and the range of suitable habitats limited by altitudinal zonation. In addition, disturbance of the animals during the rut may lead to a decrease in numbers, which in the longer term may threaten population survival (Ellenberg et al., 2007).

Physiological reactions in wild animals stressed by pressure from tourists give rise to changes in the chemical composition of the blood (Tapper, 2006). Elevated levels of corticosteroid derivatives were found in the droppings of chamois from Tatra National Park (Zwijacz-Kozica et al., 2013). Of all the herds living in the Park, those around Kasprowy Wierch are exposed to the strongest tourist pressure (Jamrozy \& Pęksa, 2004). The existence of herds in this area probably depends on the animals' ability to adapt to the large numbers of tourists by reducing the escape distance from humans to c. $25 \mathrm{~m}$ (Jamrozy et al., 2007). This is a much smaller distance than that of chamois in the Swiss Alps, where the escape distance of males with respect to humans was 103-180 m (Gander \& Ingold, 1997). In Tatra National Park, therefore, large herds of chamois could 
formerly be seen relatively close to places visited by people. But the marked increase in visitor numbers following modernization of the cable car has caused the distances between the chamois and people to increase, and larger herds to abandon these sites.

The increase in distance is the result of human pressure (Gander \& Ingold, 1997; Papouchis et al., 2001). Regardless of the type of human activity, its initial adverse impact is to reduce the chamois' range. The chamois of the Kasprowy Wierch area, which until recently occupied one of the smallest suitable habitat patches in Tatra National Park (in the growing season it was c. $2.5 \mathrm{~km}^{2}$; Jamrozy \& Pęksa, 2004), abandoned most of this area following modernization of the cable car.

Fragmentation and habitat loss are fundamental threats to global biodiversity. They can isolate and reduce populations, weaken adaptive capabilities, increase the incidence of inbreeding and restrict reproduction, thereby enhancing the probability of species' extinctions (Ebert et al., 2002; Reed \& Frankham, 2003). These are key dangers to the populations of the Balkan chamois Rupicapra rupicapra balcanica (Shackleton, 1997), exposed to significant hunting and tourist pressure.

The decrease in the herd size of the chamois on Kasprowy Wierch is not a result of population changes observed in the Tatra Mountains because the population increased significantly between 1999-2001 and 2008-2010. The mechanism governing the decrease in observed herd sizes as a result of intensified human pressure may resemble the behaviour elicited by predator pressure (Frid \& Dill, 2002). It is likely that male chamois, which tend to form smaller herds (Jamrozy et al., 2007), are more tolerant than females and young of habitats that are subject to greater threats and disturbance (Childress \& Lung, 2003; Grignolio et al., 2007). In disturbed areas the percentage of female chamois decreased more than that of males, and the number of young accompanying female herds dropped significantly. At the same time, the decrease in family herd size compels the individuals in the herd to raise their levels of vigilance (Roberts, 1996; Kluever et al., 2008).

The amount of time that ungulates devote to vigilance is a function of group size, which, apart from the social composition of the herd, may depend on other environmental factors, such as the steepness of the terrain (Manor \& Saltz, 2003; Tadesse \& Kotler, 2012) or the frequency of disturbance (Berger, 1978; Casey et al., 2012). Chamois should therefore occur in larger groups in insecure habitats. The main natural threats to chamois are the wolf Canis lupus and lynx Lynx lynx. Both predators avoid proximity to people and may follow chamois herds in remote areas. In 2008-2010 the size of the herds increased with distance to tourist infrastructure; this could potentially be a result of greater pressure from predators in areas further from the infrastructure.
Human activities in high-mountain ecosystems should consider the wild species inhabiting these areas, and information regarding the threats caused by people should be given prominent exposure in important natural areas. This is particularly important in environments that are subject to strong tourist pressure, where the numbers of tourists should be limited and controlled. In the absence of appropriate conservation tools, some populations of highmountain species, including the Tatra chamois, may decrease or potentially become locally extinct.

\section{Acknowledgements}

Information on the number of tourists was collected by the Tatra National Park. We wish to express our gratitude to Marco Festa-Bianchet and an anonymous referee for their constructive comments. This work is dedicated to the memory of the late Jakub Mucha, our friend, who loved the mountains and their nature.

\section{References}

Aulagnier, S., Giannatos, G. \& Herrero, J. (2008) Rupicapra rupicapra. In IUCN Red List of Threatened Species v. 2014.1. Http:// www.iucnredlist.org [accessed 1 July 2014].

Beale, C.M. \& Monaghan, P. (2004) Human disturbance: people as predation-free predators? Journal of Applied Ecology, 41, 335-343.

BERGER, J. (1978) Group size, foraging, and antipredator ploys: an analysis of bighorn sheep decisions. Behavioural Ecology and Sociobiology, 4, 91-99.

Bradshaw, C.J.A., Boutin, S. \& Hebert, D.M. (1998) Energetic implications of disturbance caused by petroleum exploration to woodland caribou. Canadian Journal of Zoology, 76, 1319-1324.

CAMP, R.J. \& KNight, R.L. (1998a) Rock climbing and cliff bird communities at Joshua Tree National Park, California. Wildlife Society Bulletin, 26, 892-898.

CAMP, R.J. \& KNiGHT, R.L. (1998b) Effects of rock climbing on cliff plant communities at Joshua Tree National Park, California. Conservation Biology, 12, 1302-1306.

Casey, L., Brown, C.L., Hardy, A.R., Barber, J.R., Fristrup, K.M., Crooks, K.R. \& Angeloni, L.M. (2012) The effect of human activities and their associated noise on ungulate behavior. PLoS ONE, $7(7)$, e40505.

Cederna, A. \& Lovari, S. (1985) The impact of tourism on chamois feeding activities in an area of the Abruzzo National Park, Italy. In The Biology and Management of Mountain Ungulates (ed. S. Lovari), pp. 216-225. Croom Helm, London, UK.

Childress, M.J. \& Lung, M.A. (2003) Predation risk, gender and the group size effect: does elk vigilance depend upon the behaviour of conspecifics? Animal Behavior, 66, 389-398.

CHudí K, I. (1969) Ursachen der Verluste und der Einfluss der grossen Raubtiere auf die Population des Schalenwildes im Tatra-

Nationalpark. Folia Venatoria, 4, 69-84.

Czochański, J. T. (2002) Ruch turystyczny w Tatrzańskim Parku Narodowym. In Użytkowanie turystyczne parków narodowych. Ruch turystyczny—zagospodarowanie-konflikty—zagrożenia (ed. J. Partyka), pp. 385-404. Ojcowski Park Narodowy, Ojców, Poland.

Ebert, D., HaAg, C., Kirkpatrick, M., Riek, M., Hottinger, J.W. \& PAJUnen, V.I. (2002) A selective advantage to immigrant genes in a Daphnia metapopulation. Science, 295, 485-488. 
Ellenberg, U., Setiawan, A.N., Cree, A., Houston, D.M. \& SEDDON, P.J. (2007) Elevated hormonal stress response and reduced reproductive output in Yellow-eyed penguins exposed to unregulated tourism. General and Comparative Endocrinology, 152, 54-63.

EngGist-DÜblin, P. \& Ingold, P. (2003) Modelling the impact of different forms of wildlife harassment, exemplified by a quantitative comparison of the effects of hikers and paragliders on feeding and space use of chamois Rupicapra rupicapra. Wildlife Biology, 9, 37-45.

Ewers, R.M. \& Didham, R.K. (2006) Confounding factors in the detection of species responses to habitat fragmentation. Biological Reviews, 81, 117-142.

Frid, A. \& Dill, L.M. (2002) Human-caused disturbance stimuli as a form of predation risk. Conservation Ecology, 6, 11.

Gander, H. \& Ingold, P. (1997) Reactions of male alpine chamois Rupicapra r. rupicapra to hikers, joggers and mountain bikers. Biological Conservation, 79, 107-109.

GąsIENICA - ByrCyn, W. (2001) Rupicapra rupicapra (Linné, 1758). Chamois. In Polish Red Data Book of Animals-Vertebrates (ed. Z. Głowaciński), pp. 106-108. PWRiL, Warsaw, Poland.

Gordon, I.J. \& Illius, A.W. (1989) Resource partitioning by ungulates in the Isle of Rhum. Oecologia, 79, 383-389.

Gössling, S. (2002) Global environmental consequences of tourism. Global Environmental Change, 12, 283-302.

Grignolio, S., Rossi, I., Bassano, B. \& Apollonio, M. (2007) Predation risk as a factor affecting sexual segregation in Alpine Ibex. Journal of Mammalogy, 88, 1488-1497.

Hamr, J. (1988) Disturbance behaviour of chamois in an Alpine Tourist Area of Austria. Mountain Research and Development, 8 , $65-73$.

Holmes, T.L., Knight, R.L., Stegall, L. \& Craig, G.R. (1993) Responses of wintering grassland raptors to human disturbance. Wildlife Society Bulletin, 21, 461-468.

Ingold, P., Schnidrig-Petrig, R., Marbacher, H., Pfister, U. \& Zeller, R. (1996) Tourismus/Freizeitsport und Wildtiere im Schweizer Alpenraum. Schriftenreihe Umwelt Nr. 262, BUWAL, Bern, Switzerland.

Jamrozy, G. \& PęKSA, Ł. (2004) Numbers, distribution and population changes of the Tatra chamois Rupicapra rupicapra tatrica Blahout, 1971. Nature Conservation, 60, 63-73.

Jamrozy, G., Pęksa, E., Urbanik, Z. \& Gąsienica-Byrcyn, W. (2007) The Tatra chamois Rupicapra rupicapra tatrica. Tatra National Park, Zakopane, Poland.

Kluever, B.M., Breck, S.W., Howery, L.D., Krausman, P.R. \& Bergman, D.L. (2008) Vigilance in cattle: the influence of predation, social interactions, and environmental factors. Rangeland Ecology and Management, 61, 321-328.

Körner, C. (2004) Mountain biodiversity, its causes and function. Ambio, 13, 11-17.

Krajick, K. (1999) Scientists and climbers discover cliff ecosystems. Science, 283, 1623-1625.

Limanónka, D., Cebulak, E., Cichocki, J., Kilar, P. \& Pyrc, R. (2008) Informator klimatyczny. 70 lat Wysokogórskiego Obserwatorium Meteorologicznego na Kasprowym Wierchu. IMGW, Kraków, Poland.

MANOR, R. \& SALTZ, D. (2003) Impact of human nuisance disturbance on vigilance and group size of a social ungulate. Ecological Applications, 13, 1830-1834.

Papouchis, C.M., Singer, F.J. \& Sloan, W.B. (2001) Responses of desert bighorn sheep to increased human recreation. Journal of Wildlife Management, 65, 573-582.

Parker, K.L., Robbins, Ch.T. \& Hanley, T.A. (1984) Energy expenditures for locomotion by mule deer and elk. Journal of Wildlife Management, 48, 474-488.
Patterson, I.J. (1988) Responses of Apennine chamois to human disturbance. Zeitschrift fur Säugetierkunde, 33, 245-252.

Pépin, D., Lamerenx, F., Chadelaud, H. \& Recarte, J.M. (1996) Human-related disturbance risk and distance to cover affect use of montane pastures by Pyrenean chamois. Applied Animal

Behavioural Science, 46, 217-228.

Reed, D.H. \& Frankham, R. (2003) Correlation between fitness and genetic diversity. Conservation Biology, 17, 230-237.

Roberts, G. (1996) Why individual vigilance declines as group size increases. Animal Behavior, 51, 1077-1086.

SChnidrig-Petrig, R. \& Ingold, P. (2001) Effects of paragliding on alpine chamois. Wildlife Biology, 7, 285-294.

Shackleton, D.M. (ed.) \& IUCN/SSC Caprinae Specialist Group (1997) Wild Sheep and Goats and their Relatives: Status Survey and Conservation Action Plan for Caprinae. IUCN, Gland, Switzerland, and Cambridge, UK.

Sibbald, A.M., Hooper, R.J., McLeod, J.E. \& Gordon, I.J. (2011) Responses of red deer (Cervus elaphus) to regular disturbance by hill walkers. European Journal of Wildife Research, $57,817-825$.

Skawiński, P. \& KrZan, Z. (2002) Postępy w restytucji terenów erozyjnych kopuły Kasprowego Wierchu w latach 1993-2001. In Przemiany środowiska przyrodniczego Tatr (ed. W. Borowiec), pp. 407-411. Kraków-Zakopane, Poland.

SPEHn, E.M. \& Körner, C. (2005) A global assessment of mountain biodiversity and its function. Global Change and Mountain Regions, 1, 393-400.

TAdesse, S.A. \& Kotler, B.P. (2012) Impact of tourism on Nubian ibex (Capra nubiana) revealed through assessment of behavioral indicators. Behavioural Ecology, 23, 1257-1262.

TAPper, R. (2006) Wildlife Watching and Tourism: A Study on the Benefits and Risks of a Fast Growing Tourism Activity and its Impacts on Species. UN Environment Programme/Convention on Migratory Species Secretariat, Bonn, Germany.

Thiel, D., Jenni-Eiermann, S., Braunisch, V., Palme, R. \& Jenni, L. (2008) Ski tourism affects habitat use and evokes a physiological stress response in capercaillie Tetrao urogallus: a new methodological approach. Journal of Applied Ecology, 45, $845-853$.

Thiel, D., Jenni-Eiermann, S. \& Palme, R. (2005) Measuring corticosterone metabolites in droppings of Capercaillies (Tetrao urogallus). Annals of the New York Academy of Sciences, 1046, 96-108.

Thiel, D., Ménoni, E., Brenot, J.F. \& Jenni, L. (2007) Effects of recreation and hunting on flushing distance of Capercaillie. Journal of Wildlife Management, 71, 1784-1792.

ZAR, J.H. (1999) Biostatistical Analysis, 4th edition. Prentice Hall, Upper Saddle River, USA.

ZARĘBA, D. (2008) Ekoturystyka. PWN, Warsaw, Poland.

Zwijacz-Kozica, T., Selva, N., Barja, I., Silván, G., Martínez-Fernández, L., Illera, J.C. \& Jodeowski, M. (2013) Concentration of fecal cortisol metabolites in chamois in relation to tourists pressure in Tatra National Park (South Poland). Acta Theriologica, 58, 215-222.

\section{Biographical sketches}

ŁUKASZ PĘKSA takes an active part in research and monitoring projects in Tatra National Park, and is interested in nature conservation and human impacts on the environment of the Tatra Mountains. Micha£ Ciach's area of research is animal ecology and conservation, with a particular focus on human impacts in mountain areas. 